\title{
Subfossil Cladocera as a powerful tool for paleoecological reconstruction
}

\author{
Monica Tolotti, ${ }^{1 *}$ Manuela Milan, ${ }^{2}$ Krystyna Szeroczyńska ${ }^{3}$ \\ ${ }^{1}$ Sustainable Agro-ecosystems and Bioresources, Research and Innovation Centre (CRI), Fondazione E. Mach, Via E. Mach 1, 38010 \\ San Michele all'Adige, TN, Italy \\ ${ }^{2}$ Department of Ecology and Environmental Sciences (EMG), Umeå University, Linnaeus väg 6, 90187 Umeå, Sweden \\ ${ }^{3}$ Institute of Geological Sciences, Polish Academy of Sciences, Research Centre Warsaw, Twarda 51/55, PL 00818 Warsaw, Poland \\ *Corresponding author: monica.tolotti@fmach.it
}

Key words: Cladocera, paleoecology, lakes, sediments, human impact, climate change.

Received: December 2016. Accepted: December 2016.

\section{INTRODUCTION}

Subfossil Cladocera (Crustacea, Branchiopoda) represent one of the most valuable biological proxies preserved in lake sediments that can be studied for reconstruction purposes (Kohrola and Rautio, 2011). They are widespread in both the pelagic and littoral zones of lakes of different geographical distribution, altitude and typology, where they often represent the dominant component of zooplankton in terms of biomass. The chitinous parts of their body are well preserved in lake sediments, and the taphonomic taxonomy is well established, thanks to the numerous studies that followed the first pioneer works by Frey (1960).

Cladocera play a key ecological role in freshwater ecosystems, as they occupy an intermediate position in the food web between primary producers (phytoplankton) and primary consumers (invertebrates and fish). As a consequence, subfossil Cladocera remains have the capability to track long term changes in both bottom-up drivers (such as nutrients, physical and chemical stressors) and top down regulators, such as invertebrate and fish predation (e.g., Jeppesen et al., 2001; Szeroczyńska, 2006; Perga et al., 2015).

The changes in taxonomical composition of subfossil Cladocera, which mainly includes Bosminidae and Chydoridae, and secondly Daphniidae, have been increasingly investigated during the last decades and successfully used to track past environmental changes related to nutrient enrichment (Lotter et al., 1998; Bigler et al. 2007; Manca et al., 2007; Nevalainen and Luoto, in press), acidification and calcium decline (Krause and Dellin, 1986; Paterson, 1994; Jeziorski et al., 2008), chemical contamination (Korosi and Smol, 2012a; Labaj et al., 2016), hydrological changes (Korhola et al., 2005; Nevalainen et al., 2011), submerged macrophytes (Davidson et al., 2011a), and climate change (Lotter et al., 1997; Kamenik et al., 2007; Ko- rponai et al., 2011; Nevalainen et al., 2013; Zawiska et al., 2015). The strong response of Cladocera remains to environmental variability led to inference methods for quantitative reconstruction of past lake water variables, especially phosphorus (Brodersen et al., 1998), lake depth (Davidson et al., 2011b; Nevalainen et al., 2011), and water temperature (Duigan and Birks 2000; Lotter et al., 2000).

In addition, subfossil cladoceran remains preserved in lakes sediments have the very valuable capability to allow reconstructing past changes in the lake food-web induced by the predation pressure by planktivorous fish (e.g., Korosi et al., 2013). Information on past fish populations and predation pressure on lacustrine zooplankton is in many case scattered, partial, or controversial, as it often relies on imprecise historical data, or on catch records from sport or commercial fisheries, the latter being biased by temporal changes in the catches of certain species due to their fluctuating commercial value. Within this context, changes in species composition and abundances of Cladocera remains can support the indirect reconstruction of food web changes in both temperate and high altitude/high latitude lakes (which are mainly naturally fishless, but experienced historical legal or illegal fish introductions), thus fostering conservation and restoration actions (e.g., Tiberti et al., 2014).

Recent investigations revealed that not only species composition and abundance, but also morphology of cladoceran remains can be used for ecological reconstructions. It is well established that invertebrate and fish predation can affect body size, morphology and pigmentation of Cladocera (Jeppesen et al., 2002; Hansson, 2004; Guilizzoni et al., 2006;). However, pigmentation has been recently used also to track changes in underwater UV radiation in relation to solar activity (Nevalainen and Rautio, 2014) and changes in water DOC concentrations, the latter in relation to lake productivity (Nevalainen et al, 2016) or changing land use within the lake catchment (e.g., 
a-forestation, water regulation). Isotopic composition of cladoceran remains also revealed to be a very time-effective and promising tool for interpreting changes in lake food web and functionality (Perga et al., 2010; Perga, 2011).

Nevertheless, a set of factors still hamper the interpretation of sedimentary Cladocera results, and, in turn, the exploitation of the great potential of this biological proxy for the reconstruction of past lake evolution. Firstly, taxonomy of subfossil Cladocera is well established for temperate and boreal regions of Europe and North America (Szeroczyńska and Sarmaja-Korionen, 2007; Korosi and Smol, 2012b), whereas only a few works has been published for tropical regions (Cuna et al., 2014; Sinev and Zawisza, 2013; Szeroczyńska et al., 2015). Much work remains to be done also to evaluate how well taphonomic Cladocera represent the living communities (Kattel et al., 2007; Alric and Perga, 2011; Kirillova et al., 2016), and how preservation of remain type and species in the sediment can be affected by water characteristics, such as oxygenation, $\mathrm{pH}$ and chemical composition. Sedimentation dynamics can also affect spatial distribution of remains in the lake sediments (Alric and Perga, 2011). Finally, the interpretation of sediment records is complicated by the reciprocal interactions between multiple drivers, such as climate and nutrients, which can produce additive, competitive or synergic effects (Battarbee et al., 2012). Although the multi-proxy paleoecological approach and the comparison of sediment records with limnological data (e.g. Manca et al., 2007; Bennion et al., 2015) can help disentangling the effects of multiple drivers, more studies are still necessary to make the interpretation of the Cladocera sediment records more straightforward.

The first Subfossil Cladocera Workshop was initiated by Prof. Atte Korhola in 1999 (Helsinki) with the aim of getting together specialists, young researchers and students working on various aspects of Cladocera remains in lake sediments in order to share knowledge, to foster discussion on new ecological findings and ideas, and to practice species identification at the microscope under the guidance of expert taxonomists.

The XIV Subfossil Cladocera Workshop was organized within this same spirit and held at Levico Terme (Italy) from $5^{\text {th }}$ to $8^{\text {th }}$ April 2016. The 30 participants (Fig. 1) from 9 countries (Czech Republic, Finland, France, Germany, Hungary, Italy, Poland, Russia, UK) were almost equally distributed between senior, young scientists and students, what promoted the transfer of knowledge and experience among generations. One special objective of this workshop was to stimulate the discussion on possible future developments of Cladocera-based paleoecological reconstructions based on relatively new approaches, such as the "resurrection ecology" techniques, the study of isotopic signatures in body and ephippia remains, and the statistical treatment of multiproxy sediment data.

\section{THEMATIC PAPERS}

The thematic papers grouped in this volume represent the outcome of presentations and discussions held at the XIV Subfossil Cladocera Workshop. The contributions focus on taxonomy, diversity, distribution of Cladocera remains in lake sediments in Europe and America, as well as on the subfossil Cladocera capability to track past changes in both bottom-up and top-down drivers of lake ecological dynamics.

Several papers aimed at reconstructing the environmental evolution of temperate European lakes at secular (Milan et al., 2016) or millennial (Niska, 2016; Szeroczyńska, 2016; Zawisza et al., 2016) scales. The contribution by Milan et al., (2016) showed how the multiproxy approach, and in particular the combination of biological proxies and geochemical analyses, could improve the understanding of the relation between cladoceran communities and hydrological variability. The paleolimnological studies at millennial scale investigated the relations between Cladocera and environmental drivers in stages where human impact was still absent or negligible, thus allowing the discrimination of climate related effects. Korponai et al. (2016) used subfossil Cladocera to distinguish lentic and lotic stages in oxbow lakes along the River Tisza (Hungary), thus demonstrating the potential of cladoceran remains to reconstruct changes in the hydrological regimen of transitional water ecosystems.

The thematic section of this volume tackled also the taxonomic issue. Wojewódka et al. (2016) presented a first description of Cladocera diversity in superficial sediments of 29 lakes of different altitude and size in Central America, thus contributing to the improvement of the cladoceran taxonomy within this still scarcely investigated region. On the other side, Zawiska et al. (2016) described a time and cost effective method to prepare subfossil Cladocera for SEM analysis, which allows the observation of taxonomically important details of the structure and ornamentation of carapace and spines.

Finally, several contributions studied the importance of morphological variability of Cladocera remains in tracking long term environmental and ecological changes. Leppänen and Weckström (2016) explored the potential use of changes in size and preservation level of Daphnia caudal spines to track fishing and forestry activities, as well as changes in water $\mathrm{pH}$. Milan et al. (2016) analyzed changes in Bosminidae and Daphniidae body size and appendages length to reconstruct major changes in the lake food-web, outlining nutrient enrichment and appearance of predator Cladocera species as the major drivers of size changes. Szeroczyńska (2016) related the presence of extreme Eubosmina morphs, observed in a German lake, to stages of particularly pronounced water turbulence and turbidity. Finally, Bérubé Tellier et al. (2016) demonstrated as varia- 
tions in resting eggs (ephippia) pigmentation can be used to track changes in predation pressure by fish and changes in water DOC concentration in relation to catchment land use. In conclusion, the thematic papers included in this vol- ume consolidate the indicator value of subfossil Cladocera in both classical and more novel paleolimnological approaches, outlining at the same time several research topics, which need to be further developed in the near future.

\section{Sirmione, April $7^{\text {th }} 2016$}

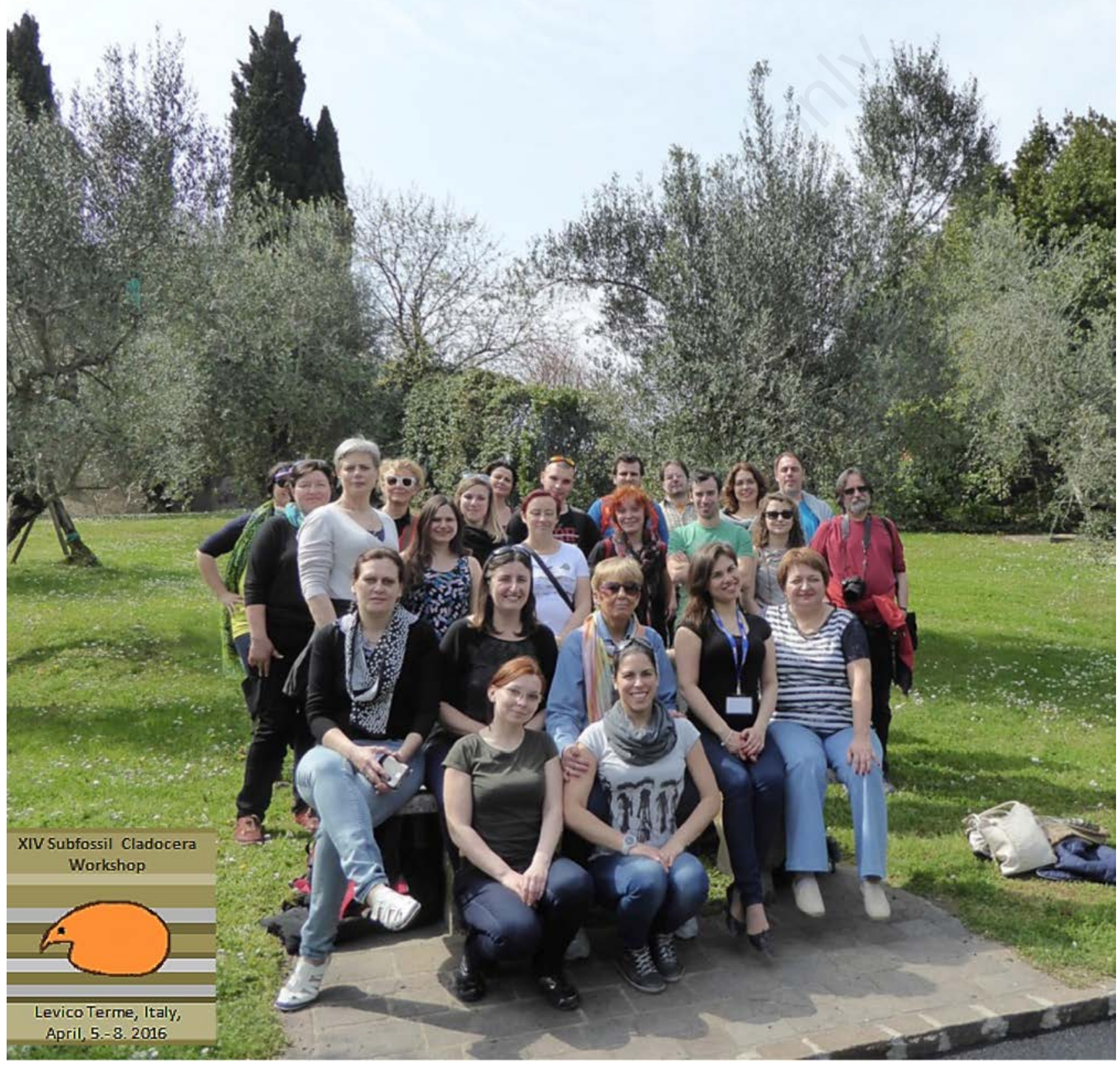

Fig. 1. The participants of the XIV Subfossil Cladocera Workshop during the excursion at Lake Garda. 


\section{REFERENCES}

Alric B, Perga ME, 2011. Effects of production, sedimentation and taphonomic processes on the composition and size structure of sedimenting cladoceran remains in a large deep subalpine lake: paleo-ecological implications. Hydrobiologia 676:101-116.

Battarbee RW, Anderson NJ, Bennion H, Simpson GL, 2012. Combining limnological and palaeolimnological data to disentangle the effects of nutrient pollution and climate change on lake ecosystems: problems and potential. Freshwater Biol. 57:2091-2106.

Bennion H, Davidson TA, Sayer CD, Simpson G, Rose NL, Sadler J, 2015. Harnessing the potential of the multi-indicator palaeolimnological approach: an assessment of the nature and causes of ecological changes in a eutrophic shallow lake. Freshwater Biol. 60:1423-1442.

Bérubé Tellier A, Drevnick PE, Bertolo A, 2016. Brook trout (Salvelinus fontinalis) extinction in small boreal lakes revealed by ephippia pigmentation: a preliminary analysis. Adv. Oceanol. Limnol. 7:6215.

Bigler C, von Gunten L, Lotter AF, Hausmann S, Blass A, Ohlendorf C, Sturm M, 2007. Quantifying human-induced eutrophication in Swiss mountain lakes since AD 1800 using diatoms. Holocene 17:1141-1154.

Brodersen KP, Whiteside MC, Lindegaard C, 1998. Reconstruction of trophic state in Danish lakes using subfossil chydorid (Cladocera) assemblages. Can. J. Fish. Aquat. Sci. 55:10931103.

Cuna E, Zawisza E, Caballero M, Ruiz-Fernández AC, LozanoGarcía S, Alcocer J, 2014. Environmental impacts of Little Ice Age cooling in central Mexico recorded in the sediments of a tropical alpine lake. J. Paleolimnol. 51:1-14.

Davidson TA, Sayer C, Perrow M, Bramm M, Jeppesen E, 2007. Are the controls of species composition similar for contemporary and sub-fossil cladoceran assemblages? A study of 39 shallow lakes of contrasting trophic status. J. Paleolimnol. 38:117-134.

Davidson TA, Bennion H, Jeppesen E, Clarke GH, Sayer CD, Morley D, Odgaard BV, Rasmussen P, Rawcliffe R, Salgado J, Simpson GL, Amsinck SL, 2011a. The role of cladocerans in tracking long-term change in shallow lake trophic status. Hydrobiologia 676:299-315.

Davidson T A, Amsinck SL, Bennike O, Christoffersen K, Landkildehus F, Lauridsen TL, Jeppesen E, 2011b. Inferring a single variable from assemblages with multiple controls: getting into deep water with cladoceran lake depth transfer functions. Hydrobiologia 676:299-315.

Duigan CA, Birks HH, 2000. The late-glacial and earlyHolocene palaeoecology of cladoceran microfossil assemblages at Kråkenes, western Norway, with a quantitative reconstruction of temperature changes. J. Paleolimnol. 23:67-76.

Frey D G, 1960. The ecological significance of cladoceran remains in lake sediments. Ecology 41:684-699.

Frossard V, Verneaux V, Milelt L, Jenny JP, Arnaud F, Magny M, Perga ME, 2014. Reconstructing long-term changes (150 years) in the carbon cycle of a clear-water lake based on the stable carbon isotope composition $\left(\delta^{13} \mathrm{C}\right)$ of chironomid and cladoceran subfossil remains. Freshwater Biol. 59:789-802.
Guilizzoni P, Lami A, Manca M, Musazzi S, Marchetto A, 2006. Palaeoenvironmental changes inferred from biological remains in short lake sediment cores from the Central Alps and Dolomites. In: A. Lami and A. Boggero (eds.), Ecology of High Altitude Aquatic Systems in the Alps. Hydrobiologia 562:167-191.

Hansson LA, 2004. Plasticity in pigmentation induced by conflicting threats from predation and UV radiation. Ecology 85:1005-1016.

Jeppesen E, Leavitt P, De Meester L, Jensen JP, 2001. Functional ecology and palaeolimnology: using cladoceran remains to reconstruct anthropogenic impact. Trends Ecol. Evol. 16:191-198.

Jeppesen E, Jensen JP, Amsinck S, Landkildehus F, Lauridsen T, Mitchell SF, 2002. Reconstructing the historical changes in Daphnia mean size and planktivorous fish abundance in lakes from the size of Daphnia ephippia in the sediment. J. Paleolimnol. 27:133-143.

Jeppesen E, Nõges P, Davidson TA, Haberman J, Nõges T, Blank K, Lauridsen TL, Søndergaard M, Sayer C, Laugaste R, Johansson LS, Bjerring R, Amsinck SL, 2011. Zooplankton as indicators in lakes: a scientific-based plea for including zooplankton in the ecological quality assessment of lakes according to the European Water Framework Directive (WFD). Hydrobiologia 676:279-297.

Jeziorski A, Yan ND, Paterson AM, DeSellas AM, Turner MA, Jeffries DS, Keller B, Weeber RC, McNicol DK, Palmer ME, 2008. The widespread threat of calcium decline in fresh waters. Science 322:1374-1377.

Kamenik C, Szeroczyńska K, Schmidt R, 2007. Relationships among recent Alpine Cladocera remains and their environment: implications for climate-change studies. Hydrobiologia 594:33-46.

Kattel GR, Battarbee RW, Mackay A, Birks HB, 2007. Are cladoceran fossils in lake sediment samples a biased reflection of the communities from which they are derived? J. Paleolimnol. 38:157-181.

Kattel GR, Battarbee RW, Mackay A, Birks HJB, 2008. Recent ecological change in a remote Scottish mountain loch: an evaluation of a Cladocera-based temperature transfer-function. Palaeogeogr. Palaeoclim. Palaeoecol. 259:51-76.

Kirillova IV, van der Plicht J, Gubin SV, Zanina OG, Chernova OF, Lapteva EG, Trofimova SS, Zinovyev EV, Zharov AA, Fadeeva EO, van Kolfschoten T, Shidlovskiy FK, Kotov AA, 2016. Taphonomic phenomenon of ancient hair from Glacial Beringia: perspectives for palaeoecological reconstructions. Boreas 45:455-469.

Korhola A, Rautio M, 2001. Cladocera and other branchiopod crustaceans, p. 5-41. In: J.P. Smol, H.J.B. Birks and W.M. Last (eds.), Tracking Environmental Change Using Lake Sediments, Zoological Indicators. 4. Kluwer, Dordrecht.

Korhola A, Tikkanen M, Weckström J, 2005. Quantification of Holocene lake-level changes in Finnish Lapland using a Cladocera-lake depth transfer model. J. Paleolimnol. 34:175-190.

Korosi JB, Smol JP, 2012a. Examining the effects of climate change, acidic deposition, and copper sulphate poisoning on long-term changes in cladoceran assemblages. Aquat. Sci. 74:781-792.

Korosi JB, Smol JP, 2012b. An illustrated guide to the identifi- 
cation of cladoceran subfossils from lake sediments in northeastern North America: part 1 - the Daphniidae, Leptodoridae, Bosminidae, Polyphemidae, Holopedidae, Sididae, and Macrothricidae. J. Paleolimnol. 48:571-586.

Korosi JB, Kurek J, Smol, JP, 2013. A review on utilizing Bosmina size structure archived in lake sediments to infer historic shifts in predation regimes. J. Plankton Res. 35:444460.

Korponai J, Magyari EM, Buczkó K, Iepure S, Namiotko T, Czakó D, Kövér C, Braun M, 2011. Cladocera response to late glacial to early Holocene climate change in a South Carpathian mountain lake. Hydrobiologia 676:223-235.

Korponai J, Gyulai I, Braun M, Kover C. Papp I, Forro L, 2016. Reconstruction of flood events in an oxbow lake (Marótzugi-Holt-Tisza, NE ungary) by using subfossil cladoceran remains and sediments. Adv. Oceanol. Limnol. 7:6168.

Krause-Dellin D, Steinberg C, 1986. Cladoceran remains as indicators of lake acidification. Hydrobiologia 143:129-134.

Labaj AL, Korosi JB, Kurek J, Jeziorski A, Keler WB, Smol JP, 2016. Response of Bosmina size structure to the acidification and recovery of lakes near Sudbury, Canada. J. Limnol. 75:22-29.

Leppänen JJ, Weckström, J, 2016. Varying degradation of subfossil Daphnia longispina during the past 250 years and the discovery of fossil helmet-type head shields: preliminary results. Adv. Oceanol. Limnol. 7:6293.

Lotter AF, Birks HJB, Hofmann W, Marchetto A, 1997. Modern diatom, Cladocera, chironomid, and chrysophyte cyst assemblages as quantitative indicators for the reconstruction of past environmental conditions in the Alps. I. Climate. J. Paleolimnol. 18:395-420.

Lotter AF, Birks HJB, Hofmann W, Marchetto A, 1998. Modern diatom, Cladocera, chironomid, and chrysophyte cyst assemblages as quantitative indicators for the reconstruction of past environmental conditions in the Alps. II. Nutrients. J. Paleolimnol. 19:443-463.

Lotter A, Birks H, Eicher U, Hofmann W, Schwander J, Wick L, 2000. Younger Dryas and Allerød summer temperatures at Gerzensee (Switzerland) inferred from fossil pollen and cladoceran assemblages. Palaeogeogr. Palaeoclim. Palaeoecol. 159:349-361.

Lynn DV, Hann BJ, Paterson M, 2015. Littoral cladoceran community reassembly following the cessation of disturbance. J. Paleolimnol. 54:121-135.

Manca M, Torretta B, Comoli P, Amsinck SL, Jeppesen E, 2007. Major changes in trophic dynamics in large, deep sub-alpine Lake Maggiore from 1940s to 2002: a high resolution comparative palaeo-neolimnological study. Freshwater Biol. 52:2256-2269.

Milan M, Bindler R, Tolotti M, 2016. Combining sediment Cladocera remains and geochemistry to reveal the role of a large catchment in driving changes in a small subalpine lake (Lake Ledro, N-Italy). Adv. Oceanol. Limnol. 7:6399.

Nevalainen L, Sarmaja-Korjonen K, Luoto TP, 2011. Sedimentary Cladocera as indicators of past water-level changes in shallow northern lakes. Quaternary Res. 75:430-437.

Nevalainen L, Luoto TP, Kultti S, Sarmaja-Korjonen K, 2013. Spatio-temporal distribution of sedimentary Cladocera (Crustacea: Branchiopoda) in relation to climate. J. Bio- geogr. 40:1548-1559.

Nevalainen L, Rautio M, 2014. Spectral absorbance of benthic cladoceran carapaces as a new method for inferring past UV exposure of aquatic biota. Quaternary Sci. Rev. 84:109-115.

Nevalainen L, Luoto TP (2016). Relationship between cladoceran (Crustacea) functional diversity and lake trophic gradients. Funct. Ecol. doi:10.1111/1365-2435.12737 (In press).

Nevalainen L, Rantala MV, Luoto TP, Ojala AE, Rautio M, 2016. Long-term changes in pigmentation of arctic Daphnia provide potential for reconstructing aquatic UV exposure. Quaternary Sc. Rev. 144:44-50.

Niska M, 2016. The Eemian/Early Vistulian development of the Solniki paleolake (north-eastern Poland) as shown by subfossil Cladocera. Adv. Oceanol. Limnol. 7:6217.

Paterson MJ, 1994. Paleolimnological reconstruction of recent changes in assemblages of Cladocera from acidified lakes in the Adirondack Mountains (New York). J. Paleolimnol. 11:189-200.

Perga ME, 2011. Taphonomic and early diagenetic effects on the $\mathrm{C}$ and $\mathrm{N}$ stable isotope composition of cladoceran remains: implications for paleoecological studies. J. Paleolimnol. 46:203-213.

Perga ME, Desmet M, Enters D, Reyss JL, 2010. A century of bottom-up- and top-down-driven changes on a lake planktonic food web: A paleoecological and paleoisotopic study of Lake Annecy, France. Limnol. Oceanogr. 55:803-816.

Perga ME, Frossard V, Jenny JP, Alric B, Arnaud F, Berthon V, Black JL, Domaizon I, Giguet-Covex C, Kirkham A, Magny M, Manca M, Marchetto A, Millet L, Paillès C Pignol C, Poulenard J, Reyss JL, Rimet F, Sabatim P, 2015. High-resolution paleolimnology opens new management perspectives for lakes adaptation to climate warming. Front. Ecol. Evol. 3:1-17.

Sinev A, Zawisza E, 2013. Comments on cladocerans of crater lakes of the Nevado de Toluca Volcano (Central Mexico), with the description of a new species, Alona manueli sp. Nov. Zootaxa 3647:390-400.

Szeroczyńska K, 2006. The significance of subfossil Cladocera in stratigraphy of Late Glacial and Holocene. Studia Quaternaria 23:37-45.

Szeroczyńska K, Sarmaja-Korjonen K, 2007. Atlas of subfossil Cladocera from central and northern Europe. Friends of the lower Vistula Society, Świecie: 84 pp.

Szeroczyńska K, Zawisza E, Wojewódka M, 2015. Initial time of two high altitude crater lakes (Nevado De Toluca, Central Mexico) recorded in subfossil Cladocera. Studia Quaternaria 32:109-116.

Szeroczyńska K, 2016. Long term subfossil Cladocera record from the partly varved sediment of Lake Tiefer (NE Germany). Adv. Oceanol. Limnol. 7:6297.

Tiberti R, von Hardenberg A, Bogliani G, 2014. Ecological impact of introduced fish in high altitude lakes: a case of study from the European Alps. Hydrobiologia 724:1-19.

Wojewódka M, Zawisza E, Cohuo S, Macario-González L, Schwalb A, Zawiska I, Perez L, 2016. Ecology of Cladocera species from Central America based on subfossil assemblages. Adv. Oceanol. Limnol. 7:6266.

Zawiska I, Słowiński M, Correa-Metrio A, Obremska M, Luoto TP, Nevalainen L, Woszczyk M, Milecka K, 2015. The re- 
sponse of a shallow lake and its catchment to Late Glacial climate changes - A case study from eastern Poland. Catena 126:1-10.

Zawiska I, Zawisza E, Wojewódka M, Sinev AY, 2016. Exploring the world of micro sculptures - subfossil Cladocera remains under the SEM. Adv. Oceanol. Limnol. 7:6218.
Zawisza E, Filbrandt-Czaja A, Correa-Metrio A, 2016. Subfossil Cladocera and pollen as indicators of natural and anthropogenic trophic changes of Lake Jelonek (Tuchola Forest, N Poland) during the Holocene. Adv. Oceanol. Limnol. 7:157-170. 